\title{
PRELIMINARY ASSESSMENT OF VELVET ANT (HYMENOPTERA: MUTILLIDAE) DIVERSITY IN THE DESERTS OF SOUTHERN CALIFORNIA
}

\author{
Joseph S. Wilson ${ }^{1,2}$, Kevin A. Williams ${ }^{1}$, and James P. Pitts ${ }^{1}$
}

\begin{abstract}
The deserts of southern California house a diverse and unique insect fauna. Velvet ants (Hymenoptera: Mutillidae) are common in these deserts. Velvet ants are important to ecosystem health, particularly in desert environments, because they are parasitic on the bees and wasps that help maintain overall ecosystem function. The goal of this study was to measure velvet ant diversity across the deserts of southern California. We made preliminary collections from 10 sites in a variety of areas in the western Sonoran Desert (Colorado Desert), the Mojave Desert, and the Great Basin Desert. We measured $\beta$-diversity using Sørensen's similarity index to compare velvet ant richness and relative abundance between different sites. To determine how accurate our similarity estimates were, and to gain an understanding of actual velvet ant diversity, we also compared velvet ant richness of 2 sites (Algodones Sand Dunes and Deep Canyon) using data obtained from the examination of museum specimens borrowed from over 12 museums across the West. Comparisons of velvet ant faunas between sites revealed low similarities $(0.167-0.75$ species richness only; $0.022-0.67$ both abundance and richness). Low similarity values indicate that a rich velvet ant fauna exists in the deserts of southern California.
\end{abstract}

Key words: $\beta$-diversity, Mutillidae, biodiversity, deserts, distribution, California.

Many Hymenoptera (wasps, bees, and ants) have diversified in the deserts of North America, forming a unique fauna. New World bees, for example, reach their highest diversity in the deserts of North America and Mexico (Moldenke 1979, Michener 2000). Also, the wasp family Mutillidae (velvet ants) has many arid-adapted genera-such as Dasymutilla, Odontophotopsis, and Sphaeropthalma-that have diversified extensively in the arid lands of North America.

Bees and wasps play key roles in desert ecosystems. Bees, as pollinators, have been considered keystone components of most terrestrial ecosystems, particularly in desert regions (Proctor et al. 1996, Sheffield et al. 2003, Wilson et al. 2009). Wasps are efficient predators and can be important in controlling pest insects that can severely damage an ecosystem (Hanson 1995). Many wasps are either parasitoids or primary predators of various phytophagus insects (O'Neill 2001). Healthy bee and wasp populations can aid in the maintenance of a vigorous desert flora, which is vital to a healthy desert ecosystem.

Velvet ants are solitary wasps that mostly parasitize the larvae or pupae of other wasps and bees. As such, velvet ants can play a major role in the overall health of an ecosystem. Study of a nesting aggregation of the solitary ground nesting bee Diadasia rinconis Cockerell revealed that over $40 \%$ of the bee's nest cells had been parasitized by 2 species of velvet ants, Dasymutilla foxi Cockerell and Dasymutilla vestita (Lepeletier) (Schmidt and Buchmann 1986). Parasitism rates this high suggest that velvet ants are ecologically important parasites (Schmidt and Buchmann 1986). The richness and abundance of parasitic velvet ant species may indicate the general abundance and diversity of other wasps and bees, which, in turn, may be an indicator of overall ecosystem health (J. Schmidt personal communication). While not tested on a localized scale, large-scale diversity patterns of velvet ants and their hosts indicate that a relationship exists. For example in North America, bees are most diverse in the Madrean Archipelago of southern Arizona and New Mexico (Buchmann 1995). This area also supports a rich velvet ant fauna, with more velvet ant species inhabiting this area than the entire eastern United States (Bodner et al. 2006).

Western North America contains many desert or arid environments. California, however, is 


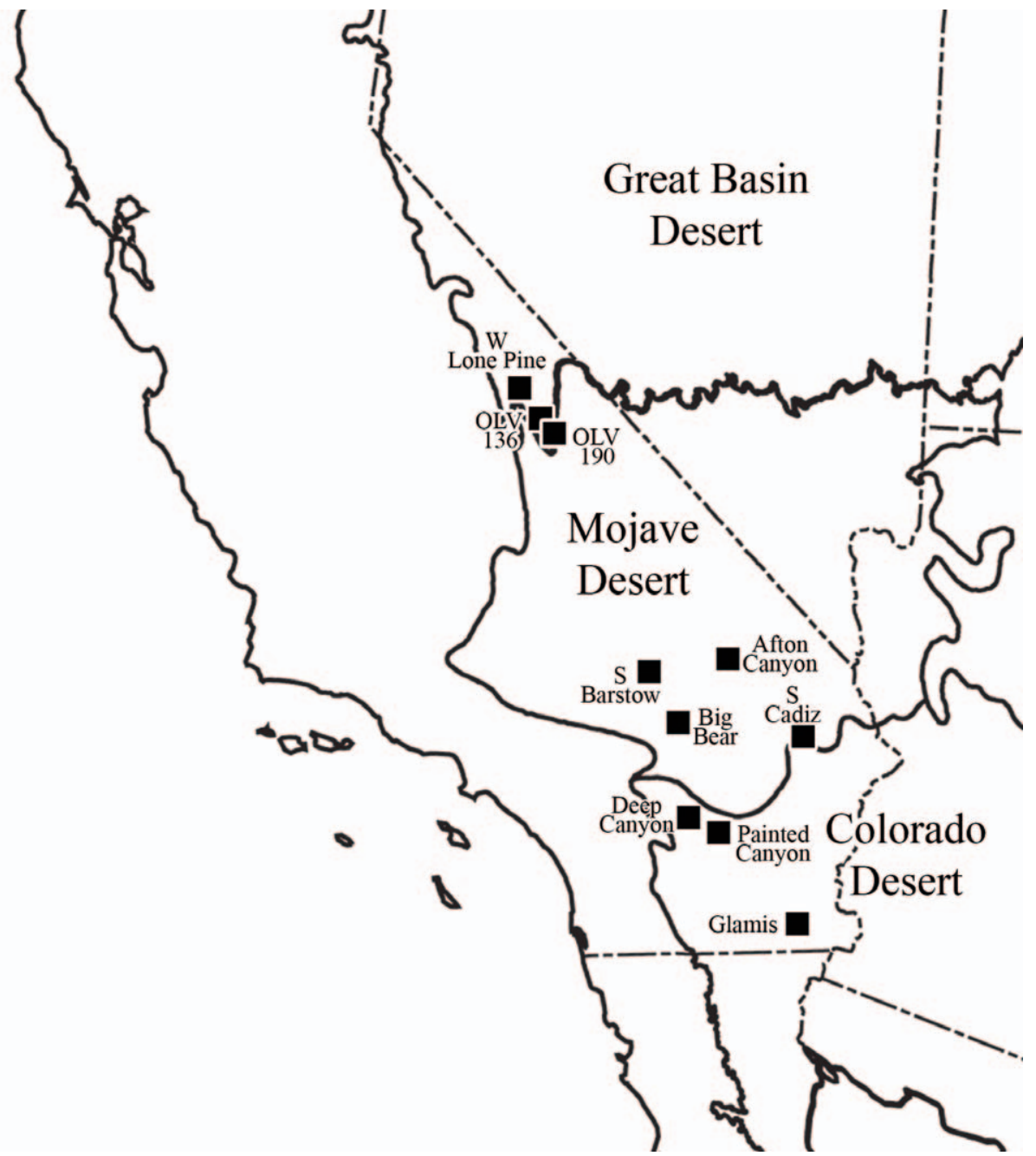

Fig. 1. Map of southern California showing locations of the collection sites (squares) and boundaries of the deserts (ecoregions). Desert boundaries follow descriptions by Omernik (1987), except for the Colorado Desert, which contains only the western portions of Omernik’s Sonoran Desert. OLV = Owens Lake Valley.

unique in that it contains portions of 3 of the 4 North American deserts. This wide array of habitats probably enabled southern California's velvet ants to develop into a unique and diverse fauna, with numerous endemic taxa. For example, Dilophotopsis paron (Cameron) lives only in the Mojave and western Sonoran deserts (Wilson and Pitts 2008), while Sphaeropthalma django Pitts and Wilson and Dasymutilla imperialis Manley and Pitts are endemic, inhabiting only the Algodones Sand Dunes in southern California (Pitts et al. 2009). Lastly, 4 species of velvet ants-all undescribed-can be found only at Boyd Deep Canyon Research
Center and in the surrounding canyons. Therefore, the varied geologic history of California likely contributed to the velvet ant diversity and endemism found in California deserts.

The goal of this study was to measure and compare the diversity of velvet ants from the deserts of southern California based on freshly collected specimens (snapshot study) as well as museum specimens (museum-based study). We collected specimens from each of the 3 deserts in southern California so that we could make diversity comparisons among these regions. In addition to our recent collections, museum specimens from 2 sites in the western Sonoran 
Desert (Algodones Sand Dunes and Deep Canyon) were compared. This comparison facilitates a more accurate and complete assessment of species diversity. Museum-based studies are beneficial because a researcher can obtain a fairly complete species list by examining specimens in the numerous collections. This type of investigation, however, is limited, because comparisons between sites can easily be biased due to varying levels of collection intensity from one site to another. Snapshot studiesstudies that investigate diversity during a small time period-can sometimes be more beneficial because comparisons can be made between sites as long as similar collection methods were employed. The comparison of museum-based analyses with snapshot-based analyses enables us to gauge the accuracy of both types of analyses.

\section{Methods}

We collected samples from a variety of landscapes in order to capture a diverse velvet ant fauna. Collection sites were located in the Great Basin Desert, the Mojave Desert, and the western Sonoran Desert (Colorado Desert; Fig. 1, Table 1). We marked all collection sites with a Garmin eTrex GPS unit. Collections were made at each site during the last week of July 2007.

We collected specimens using 3 blacklight traps and 3 fluorescent lantern traps. Specimens collected with light traps were captured in soapy water and then transferred into $95 \%$ ethanol.

All specimens were determined to species where possible using keys from Manley and Pitts (2002), Pitts and McHugh (2002), Pitts (2006), Pitts (2007), Pitts et al. (2009), and unpublished keys based on Schuster (1958). All specimens collected by the authors are housed in the Department of Biology Entomological Museum, Utah State University, Logan, Utah (EMUS).

To compare velvet ant richness and relative abundance between different sites, we measured $\beta$-diversity using 2 versions of the Sørensen's similarity index: one that includes abundance (Bray and Curtis 1957) and one that only uses presence/absence (Southwood 1978). Sørensøn's similarity index is calculated as $2 a /(2 a+$ $b+c$ ), where $a$ is the number of species in common between 2 sites and $b$ and $c$ are the 


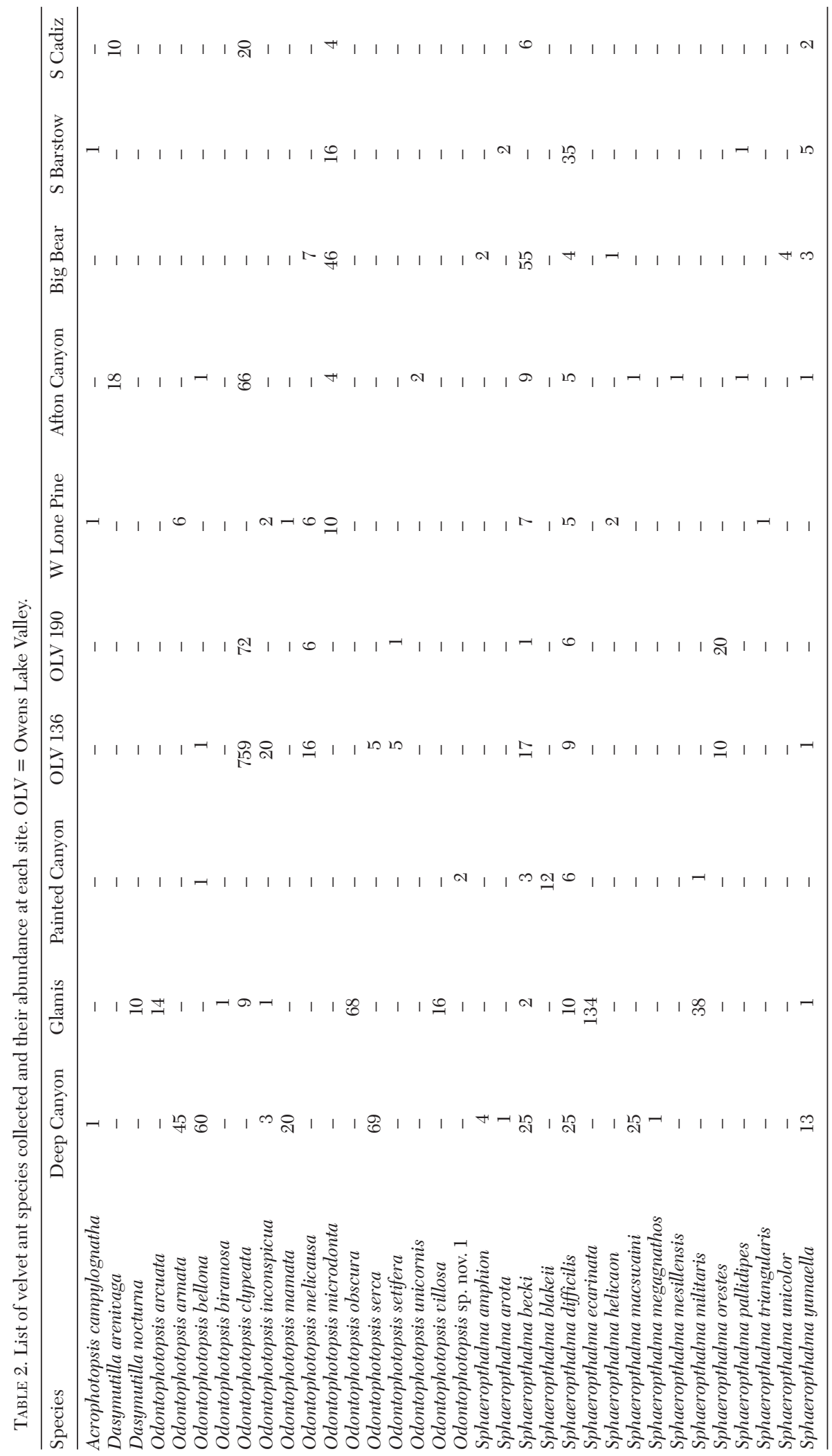


number of specimens unique to each site. Similarities were determined using EstimateS (Colwell 2005). The closer the Sørensen's similarity value is to 1 , the more similar are the compared mutillid faunas.

To determine the accuracy of our similarity estimates, and to gain an understanding of actual velvet ant diversity, we also compared velvet ant richness of 2 sites-the Algodones Sand Dunes (Glamis) (see Pitts et al. 2009) and Deep Canyon (personal observation)using data obtained from examination of museum specimens borrowed from over 12 museums across the United States. These museums included the following: ANSP_Department of Entomology, Academy of Natural Sciences, Philadelphia, Pennsylvania; CASC-Department of Entomology, California Academy of Sciences, San Francisco, California; CDFACalifornia State Collection of Arthropods, California Department of Food and Agriculture, Sacramento, California; CISC-Essig Museum of Entomology, Department of Entomological Sciences, University of California, Berkeley, California; CUIC-Cornell University Insect Collection, Department of Entomology, Cornell University, Ithaca, New York; DGMC-Donald G. Manley Personal Collection, Pee Dee Research and Education Center, Florence, South Carolina; LACM-Insect Collection, Los Angeles County Museum of Natural History, Los Angeles, California; EMUS-Entomological Museum, Department of Biology, Utah State University, Logan, Utah; NMNH-National Museum of Natural History, Smithsonian, Washington, DC; SEMC-Snow Entomological Museum, University of Kansas, Lawrence, Kansas; UCDC_-The Bohart Museum of Entomology, University of California, Davis, California; UCRC-UCR Entomological Teaching and Research Collection, University of California, Riverside, California; and UMSP-University of Minnesota Insect Collection, Department of Entomology, St. Paul, Minnesota.

The examination of museum specimens allowed us to obtain a more complete species list from both sites. Museum specimens represented collection events from as far back as 100 years ago to the present. Because of the vast number of specimens as well as the range of times and seasons collections were made, it is assumed that these species lists represent actual species richness for each site. 
TABlE 4. Species lists based on examination of museum specimens from the Algodones Sand Dunes (Glamis) and Deep Canyon. An $X$ indicates presence of the species.

\begin{tabular}{|c|c|c|}
\hline Species & Algodones Sand Dunes (Glamis) & Deep Canyon \\
\hline Acanthophotopsis dorophora & $\mathrm{X}$ & \\
\hline Acanthophotopsis falciformis & $\mathrm{X}$ & $\mathrm{X}$ \\
\hline Dasymutilla arenivaga & $\mathrm{X}$ & \\
\hline Dasymutilla atricauda & $\mathrm{X}$ & \\
\hline Dasymutilla gloriosa & $\mathrm{X}$ & $\mathrm{X}$ \\
\hline Dasymutilla imperialis & $\mathrm{X}$ & \\
\hline Dasymutilla magnifica & $\mathrm{X}$ & \\
\hline Dasymutilla nocturna & $\mathrm{X}$ & \\
\hline Lomachaeta hicksi & & $\mathrm{X}$ \\
\hline Lomachaeta snellingella & & $\mathrm{X}$ \\
\hline Odontophotopsis acmaea & $\mathrm{X}$ & $\mathrm{X}$ \\
\hline Odontophotopsis ambigua & $\mathrm{X}$ & \\
\hline Odontophotopsis arcuata & $\mathrm{X}$ & \\
\hline Odontophotopsis armata & & $\mathrm{X}$ \\
\hline Odontophotopsis aufidia & $\mathrm{X}$ & $\mathrm{X}$ \\
\hline Odontophotopsis bellona & $\mathrm{X}$ & $\mathrm{X}$ \\
\hline Odontophotopsis biramosa & $\mathrm{X}$ & \\
\hline Odontophotopsis clypeata & $\mathrm{X}$ & $\mathrm{X}$ \\
\hline Odontophotopsis inconspicua & $\mathrm{X}$ & $\mathrm{X}$ \\
\hline Odontophotopsis mamata & & $\mathrm{X}$ \\
\hline Odontophotopsis melicausa & $\mathrm{X}$ & $\mathrm{X}$ \\
\hline Odontophotopsis obscura & $\mathrm{X}$ & \\
\hline Odontophotopsis parva & $\mathrm{X}$ & \\
\hline Odontophotopsis quadrispinosa & $\mathrm{X}$ & $\mathrm{X}$ \\
\hline Odontophotopsis serca & & $\mathrm{X}$ \\
\hline Odontophotopsis setifera & & $\mathrm{X}$ \\
\hline Odontophotopsis sonora & $\mathrm{X}$ & \\
\hline Odontophotopsis unicornis & $\mathrm{X}$ & \\
\hline Odontophotopsis villosa & $\mathrm{X}$ & \\
\hline Odontophotopsis sp. nov. 1 & & $\mathrm{X}$ \\
\hline Photomorphus bicolor & $\mathrm{X}$ & \\
\hline Photomorphus clandestina & $\mathrm{X}$ & \\
\hline Sphaeropthalma acontia & $\mathrm{X}$ & \\
\hline Sphaeropthalma amphion & & $\mathrm{X}$ \\
\hline Sphaeropthalma angulifera & & $\mathrm{X}$ \\
\hline Sphaeropthalma arota & $\mathrm{X}$ & $\mathrm{X}$ \\
\hline Sphaeropthalma becki & $\mathrm{X}$ & $\mathrm{X}$ \\
\hline Sphaeropthalma blakeii & $\mathrm{X}$ & $\mathrm{X}$ \\
\hline Sphaeropthalma difficilis & $\mathrm{X}$ & $\mathrm{X}$ \\
\hline Sphaeropthalma django & $\mathrm{X}$ & \\
\hline Sphaeropthalma ecarinata & $\mathrm{X}$ & \\
\hline Sphaeropthalma ferruginea & & $\mathrm{X}$ \\
\hline Sphaeropthalma ignacio & & $\mathrm{X}$ \\
\hline Sphaeropthalma macswaini & & $\mathrm{X}$ \\
\hline Sphaeropthalma marpesia & $\mathrm{X}$ & \\
\hline Sphaeropthalma megagnathos & $\mathrm{X}$ & $\mathrm{X}$ \\
\hline Sphaeropthalma mendica & $\mathrm{X}$ & $\mathrm{X}$ \\
\hline Sphaeropthalma mesillensis & $\mathrm{X}$ & \\
\hline Sphaeropthalma militaris & $\mathrm{X}$ & \\
\hline Sphaeropthalma pallida & & $\mathrm{X}$ \\
\hline Sphaeropthalma pateli & & $\mathrm{X}$ \\
\hline Sphaeropthalma sublobata & & $\mathrm{X}$ \\
\hline Sphaeropthalma triangularis & $\mathrm{X}$ & $\mathrm{X}$ \\
\hline Sphaeropthalma yumaella & $\mathrm{X}$ & $\mathrm{X}$ \\
\hline Sphaeropthalma sp. nov. 1 & & $\mathrm{X}$ \\
\hline Sphaeropthalma sp. nov. 2 & & $\mathrm{X}$ \\
\hline Sphaeropthalma sp. nov. 3 & & $\mathrm{X}$ \\
\hline
\end{tabular}




\section{Results}

Field collecting yielded a total of 34 species from 10 sites across the deserts of southern California (Table 2). Species richness varied greatly from site to site, with the highest species richness in Deep Canyon, Riverside County. Species abundance also varied among sites. Sørensen’s similarity values calculated using species richness alone suggest a low level of similarity among the majority of sites (Table 3). When abundance was included in the calculation, similarity values dropped dramatically (Table 3). In general, $\beta$-diversity was high among most sites.

Velvet ant richness varied greatly among the 3 deserts. The Colorado Desert (western Sonoran) had the highest richness (23 species), followed by the Mojave Desert (18 species), with the Great Basin Desert having the lowest richness (16 species). Collections were made from 3 sites in the Colorado Desert, 4 sites in the Mojave Desert, and 3 sites in the Great Basin Desert. Species abundance varied widely among the 3 deserts and was not associated with collection effort, which was relatively equal in each desert. The Great Basin Desert yielded the highest number of specimens (990) followed by the Colorado Desert (622), with the fewest specimens collected in the Mojave Desert (333).

The examination of museum specimens yielded 57 total species from the Algodones Sand Dunes and Deep Canyon (Table 4). Each site, however, only housed a fraction of the total species (Algodones Sand Dunes had 39 species and Deep Canyon had 35 species), which suggests high species turnover or $\beta$ diversity between sites. The Sørensen's similarity index calculated based on species richness between sites was 0.459 .

\section{DisCUSSION}

Our analysis of museum specimens enabled us to determine if our similarity values based on field collections in 2007 were truly indicative of the faunal characteristics or if they were simply an artifact of the low collection intensity. The comparison of species richness between museum specimens from the Algodones Sand Dunes and Deep Canyon yielded a low Sørensen's similarity value of 0.459 . This value is higher than the value calculated from our collection data (0.32), yet it still suggests that the velvet ant communities at the 2 sites are significantly different. Given the biotic comparability between sites (i.e., both are in the Colorado Desert), this low similarity between the Algodones Sand Dunes and Deep Canyon is lower than may be expected. Furthermore, because of the vast number of specimens examined from several museums, it is likely that the species lists compiled from museum data are nearly complete, suggesting that the low similarity values between sites represent actual differences in species composition.

Our analyses strongly suggest that a diverse velvet ant fauna exists in these deserts, even though our data are based on a single collection at each site. Moreover, southern California deserts were experiencing extreme drought conditions at the time of collections, which may have resulted in an underestimate of actual diversity. The low similarity values among sites provide strong evidence that a much richer fauna exists in the deserts as a whole than at any one collection site.

Low similarity values did not appear to be associated with distance or desert regions. For example, in some instances the closer 2 collecting sites were to each other, the more similar were their velvet ant faunas (e.g., OLV 136 and OLV 190; 0.75 based on species richness), but closely situated collecting sites did not always result in high similarity (e.g., Painted Canyon and Deep Canyon; 0.316 based on species richness). Similarly, the sites located in the same desert region were not necessarily more similar to each other than sites located in different desert regions. For example, all 3 sites in the Colorado Desert were $<35 \%$ similar in species richness and $<7 \%$ similar when abundance and richness were considered. While low species similarity between sites is common in deserts (e.g., Goettsch and Hernández 2005), often sites in similar physiographic regions are more similar to each other than sites in different regions (Garcillán and Ezcurra 2003). The fact that low similarity values were found between sites located in the same desert suggests a high degree of $\beta$-diversity and endemism in the velvet ants of southern California.

Several velvet ant species were widespread (5 spp.) and present in at least half of the collection sites. Others were only collected at a single site (12 spp.). Many of these species, however, are common in other areas or are known to be widespread from examination of museum specimens. For example, Odontophotopsis 
unicornis Schuster was only collected at one site (Afton Canyon) but is common throughout southern Arizona. Its apparent rarity in our study area may be due to the short-term nature of this study. Four of the species that were found at only one site were collected in fairly large numbers, ranging from 14 specimens to 134 specimens (Table 2). These 4 species were all collected from the site in the Algodones Sand Dunes, which suggests these species may be endemic or largely restricted to these dunes.

Many species found in this study were collected in small numbers: over $75 \%$ of the species are represented by 50 or fewer specimens, with $41 \%$ of all species represented by 10 or fewer specimens. Four species, however, were represented by over 100 specimens, with the highest (Odontophotopsis clypeata) Schuster, represented by 926 specimens. Three of these 4 abundant species were widespread, but 1 (Sphaeropthalma ecarinata Schuster) was only collected at the Glamis site in the Algodones Sand Dunes.

The hot deserts of southern California (Colorado and Mojave deserts) house a more diverse velvet ant fauna than the cold desert (Great Basin Desert). This finding is not surprising, however, because the general trend in velvet ant diversity follows a latitudinal gradient, with the highest diversity in northern Mexico and the southwestern United States and the lowest diversity in higher latitudes (personal observation). What is surprising is that some sites in different deserts with different ecological constraints house similar velvet ant faunas, even when considering the combination of richness and abundance (e.g., OLV 190 in the Great Basin Desert and Afton Canyon in the Mojave Desert; see Table 3).

The low similarity values between sites and the high number of velvet ant taxa that are apparently endemic to areas of southern California (e.g., the Algodones Sand Dunes) may be attributed to Pleistocene climate change. Many areas in southern California maintained desertlike characteristics throughout the Pleistocene, while most of western North America was overtaken by cool mesic woodlands (Elias et al. 1992, Koehler et al. 2005). The contraction and subsequent expansion of desert environments during the Pleistocene and Holocene likely caused isolation of many velvet ant populations and shaped the biogeographic patterns of diversity we found in this study. Furthermore, patterns of diversity found in this study suggest that velvet ant distributions may be more dependent on microhabitat than previously thought. Because dissimilar velvet ant communities inhabit different sites containing similar habitats (i.e., sites located in the same desert region), there may be some unexplored niche separation causing the differences in velvet ant species composition between sites.

Velvet ant diversity in southern California deserts is likely due, in part, to the assorted suite of hosts that these deserts provide. Additionally, the heterogeneous landscapes of the southern California deserts have undoubtedly influenced the development of a species-rich velvet ant fauna. It remains unclear exactly which factors are controlling patterns of diversity in velvet ant communities, but it is apparent that a rich and unique fauna exists in the deserts of southern California. Much more work is needed for us to gain an understanding of the diversity that exists in this region.

\section{ACKNOWLEDGMENTS}

We thank the California Desert Research Fund at the Community Foundation for providing funding for this project. This research was also supported by the Utah Agricultural Experiment Station, Utah State University, Logan, Utah 84322-4810. Approved as journal paper no. 8094.

\section{Literature Cited}

Bodner, G., J. Atchley Montoya, R. Hanson, and W. ANDERSON, EDITORS. 2006. Natural heritage of the Peloncillo Mountain Region: a synthesis of science. World Wildlife Fund and Sky Island Alliance, Tucson, AZ.

Bray, J.R., AND J.T. CuRTIS. 1957. An ordination of the upland forest communities of southern Wisconsin. Ecological Monographs 27:325-349.

BuCHMANN, S.L. 1995. Diversity and importance of native bees from the Arizona/Mexico Madrean Archipelago. Pages 301-310 in L.F. DeBano, P.F. Folliott, A. Ortega-Rubio, G.J. Gottfried, R.H. Hamre, and C.B. Edminster, technical coordinators, Biodiversity and management of the Madrean Archipelago: the sky islands of southwestern United States and northwestern Mexico. General Technical Report RMGTR-264, USDA Forest Service, Tucson, AZ.

Colwell, R.K. 2005. EstimateS: statistical estimation of species richness and shared species from samples. Version 7.5. [Cited April 2008]. Available from: http:// viceroy.eeb.uconn.edu/estimates

Elias, S.A., J.I. Mead, and L.D. Agenbroad. 1992. Late Quaternary arthropods from the Colorado Plateau, Arizona and Utah. Great Basin Naturalist 52:59-67. 
Garcillán, P.P., And E. Ezcurra. 2003. Biogeographic regions and $\beta$-diversity of woody dryland legumes in the Baja California peninsula. Journal of Vegetation Science 14:859-868.

Goettsch, B., And H.M. Hernández. 2005. Beta diversity and similarity among cactus assemblages in the Chihuahuan Desert. Journal of Arid Environments 65:513-528.

Hanson, P.E. 1995. Economic importance of Hymenoptera. Pages 89-101 in P.E. Hanson and I.D. Gauld, editors, The Hymenoptera of Costa Rica. Oxford University Press, Oxford.

Koehler, P.A., R.S. Anderson, and W.G. Spaulding. 2005. Development of vegetation in the Central Mojave Desert of California during the late Quaternary. Palaeogeography, Palaeoclimatology, Palaeoecology 215:297-311.

Manley, D.G., AND J.P. PITTS. 2002. Key to the genera and subgenera of Mutillidae of America North of Mexico with description of new genus. Journal of Hymenoptera Research 11:72-101.

Michener, C.D. 2000. The bees of the world. Johns Hopkins University Press, Baltimore, MD

Moldenke, A.R. 1979. Host-plant coevolution and the diversity of bees in relation to the flora of North America. Phytologia 43:357-419.

OMERNIK, J.M. 1987. Ecoregions of the conterminous United States. Annals of the Association of American Geographers 77:118-125.

O’NeILL, K.M. 2001. Solitary wasps: behavior and natural history. Cornell University Press, Ithaca, NY.

PITTS, J.P. 2006. Review of the Sphaeropthalma imperialis species-group (Hymenoptera: Mutillidae), with descriptions of females and taxonomic notes. Zootaxa 1248:1-20.

2007. Revision of Odontophotopsis Viereck (Hymenoptera: Mutillidae), Part 1, with a description of a new genus Laminatilla. Zootaxa 1619:1-43.
PitTs, J.P., AND J.V. McHugh. 2002. Revision of Acrophotopsis (Mutillidae: Sphaeropthalminae), with a new species from Baja California. Journal of Hymenoptera Research 11:363-374.

PitTs, J.P. J.S. Wilson, K.A. Williams, and N.F. Boehme. 2009. Velvet ants (Hymenoptera: Mutillidae) of the Algodones Sand Dunes of California, USA. Zootaxa 2131:1-53.

Proctor, M., P. Yeo, And A. Lack. 1996. The natural history of pollination. Timber Press, Portland, OR.

Schmidt, J.O., And S.L. Buchmann. 1986. Are mutillids scarce? (Hymenoptera: Mutillidae). Pan-Pacific Entomologist 62:103-104.

SChuster, R.M. 1958. A revision of the sphaeropthalmine Mutillidae of America north of Mexico. II. Entomologica Americana 37:1-130.

Sheffield, C.S., P.G. Kevan, R.F. Smith, S.M. Rigby, and R.E.L. Rogers. 2003. Bee species of Nova Scotia, Canada, with new records and notes on bionomics and floral relations (Hymenoptera: Apoidea). Journal of the Kansas Entomological Society 76:357-384.

SouthwOOD, T.R.E. 1978. Ecological methods with particular reference to the study of insect populations. John Wiley \& Sons, New York, NY.

Wilson, J.S., O. Messinger, and T. Griswold. 2009. Variation between bee communities on a sand dune complex in the Great Basin Desert, North America: implications for sand dune conservation. Journal of Arid Environments 73:666-671.

Wilson, J.S., AND J.P. PITTS. 2008. Revision of velvet ant genus Dilophotopsis Schuster (Hymenoptera: Mutillidae) by using molecular and morphological data, with implications for desert biogeography. Annals of the Entomological Society of America 101:514-524.

Received 27 May 2009 Accepted 30 October 2009 